\title{
Dados Editoriais e Avaliador Homenageado
}

\author{
Franzé Costa - Editor Chefe
}

Trazemos aqui os dados editoriais relevantes referentes ao ano de 2020, além da indicação do avaliador homenageado de 2020.

\section{- Números da revista}

Na tabela abaixo, temos os dados referentes às publicações da TPA em uma perspectiva histórica, desde o primeiro volume em 2011 até o nono volume, publicado em 2020. Esses dados são extraídos do sistema OJS, nos quais observamos um evidente crescimento das submissões até 2018, uma redução em 2019 e um incremento em 2020.

Entendemos que a nova linha editorial da revista foi se tornando mais conhecida e a TPA converteu-se em uma referência para submissões de mais e mais autores. Também é possível que o trabalho remoto, em que as pessoas estão mais tempo em casa por conta da pandemia Covid-19 tenha estimulado os autores a atualizarem seus estudos e buscarem a submissão.

Tabela 1 - Dados editoriais

\begin{tabular}{l|c|c|c|c|c|c|c|c|c|c}
\hline \multicolumn{1}{c}{ Indicador } & $\mathbf{2 0 1 1}$ & $\mathbf{2 0 1 2}$ & $\mathbf{2 0 1 3}$ & $\mathbf{2 0 1 4}$ & $\mathbf{2 0 1 5}$ & $\mathbf{2 0 1 6}$ & $\mathbf{2 0 1 7}$ & $\mathbf{2 0 1 8}$ & $\mathbf{2 0 1 9}$ & $\mathbf{2 0 2 0}$ \\
\hline Edições publicadas & 1 & 0 & 4 & 1 & 2 & 3 & 2 & 2 & 2 & 2 \\
Total de submissões: & 7 & 32 & 48 & 34 & 45 & 54 & 66 & 102 & 74 & 131 \\
Rejeições no desk & 1 & 5 & 12 & 5 & 20 & 26 & 26 & 36 & 23 & 85 \\
review & & & & & & & & & & \\
Avaliados pelos pares & 6 & 27 & 36 & 29 & 25 & 28 & 40 & 66 & 51 & 46 \\
$\quad$ Aceito & $6(100 \%)$ & $21(78 \%)$ & $21(58 \%)$ & $16(55 \%)$ & $18(72 \%)$ & $19(68 \%)$ & $22(55 \%)$ & $18(27 \%)$ & $24(47 \%)$ & $30(65 \%)$ \\
Rejeitado & $0(0 \%)$ & $6(22 \%)$ & $15(42 \%)$ & $13(45 \%)$ & $7(28 \%)$ & $9(32 \%)$ & $18(45 \%)$ & $48(73 \%)$ & $30(53 \%)$ & $16(35 \%)$ \\
Tempo de avaliação & 0 & 95 & 79 & 63 & 113 & 83 & 131 & 62 & 87 & 45 \\
Tempo até a & 144 & 311 & 299 & 271 & 319 & 217 & 232 & 94 & 230 & $*$ \\
publicação & & & & & & & & & \\
\hline
\end{tabular}

* A partir de 2020, a TPA passou a adotar a publicação em 'ahead of print', com editoração e publicação do artigo tão logo este recebe aprovação.

Se a mudança de plataforma alterou os dados da TPA de 2018 para 2019, a estabilização de uso permitiu retomar a normalidade do processo editorial, com o tempo médio de revisão reduzido em 2020. Também, em 2020, a editoria optou por tornar mais rígido o processo de avaliação na etapa de desk review, reduzindo a demanda sobre avaliadores, o que permitiu uma escolha de avaliadores sabidamente mais responsivos.

\section{- Avaliador homenageado}

A TPA teve dezenas de avaliadores em 2020, muitos dos quais já colaboradores de outras avaliações em anos passados. A todos registramos nosso agradecimento, mas, de modo especial, homenageamos o professor Gilnei Luiz Moura, da Universidade Federal de Santa Maria (UFSM) que se destacou pela densidade das observações e recomendações aos autores dos artigos submetidos, pelo zelo com detalhes e pelo discernimento entre o que é acessório e o que é essencial. Professor Gilnei, agradecemos o empenho e esperamos manter sua colaboração com a TPA. 